\title{
Quantification of Organic Carbon from Biomass Versus Non-Biomass Burning Emissions to Fine Aerosol
}

\author{
ATINDERPAL SINGH ${ }^{1,2, *}$ and NEERAJ RASTOGI ${ }^{2}$ \\ ${ }^{1}$ Department of Physics, Punjabi University, Patiala, Punjab, India \\ ${ }^{2}$ Geosciences Division, Physical Research Laboratory, Ahmedabad, Gujarat, India
}

(Received on 21 March 2018; Accepted on 15 September 2018)

\begin{abstract}
In the present study, size-segregated aerosol samples (in five size ranges) were collected from Patiala $\left(30.33^{\circ} \mathrm{N}, 76.40^{\circ} \mathrm{E}\right.$; $250 \mathrm{~m}$ amsl), located in the northwestern Indo-Gangetic Plain (IGP) during October 2012 to September 2013 to quantify the contribution of biomass burning (BB) to ambient organic carbon (OC) in fine aerosol. All of these samples were analyzed for major inorganic ions, whereas, particulate matter smaller than $1 \mu \mathrm{m}$ aerodynamic diameter $\left(\mathrm{PM}_{1}\right)$ were also analyzed for carbonaceous aerosol (OC, elemental carbon (EC), and water-soluble organic carbon (WSOC)). The contribution of BB derived potassium $\left(K_{B B}^{+}\right)$to ambient fine $\mathrm{K}^{+}$is found to be dominant $(77 \pm 24 \%)$ over an annual cycle. Further, regression parameters of $\mathrm{OC}$ and $K_{B B}^{+}$linear relationships are used to quantify the contribution of BB to ambient $\mathrm{OC}_{\text {in }} \mathrm{PM}_{1}$. The contribution of $\mathrm{BB}$ derived $\mathrm{OC}\left(\mathrm{OC}_{\mathrm{BB}}\right)$ to fine $\mathrm{OC}$ was significantly higher during autumn $(69 \%)$, winter $(54 \%)$ and summer (40\%) seasons in comparison to that during spring (26\%) and wet (2\%) seasons with the annual average of $41 \pm 30 \%$. Emissions from agricultural-waste burning during autumn and summer, and from bio-fuel (Babool, Cowdung cake, Eucalyptus, Jujube and Shisham) burning during winter are the major sources of ambient OC over the study region. The contribution of $\mathrm{BB}$ derived water-soluble organic carbon $\left(\mathrm{WSOC}_{\mathrm{BB}}\right.$ ) to fine WSOC exhibited similar seasonal variation as that of $\mathrm{OC}_{\mathrm{BB}}$ to fine OC. It was 75\%, 55\%, 14\%, 44\% and 5\% during autumn, winter, spring, summer and wet seasons respectively, with the annual average of $43 \pm 32 \%$. These results have implication in climate modelling, health impact assessment and planning effective mitigation strategies.
\end{abstract}

Keywords: Potassium; Tracer; OC; WSOC; Agriculture-waste Burning, India

\section{Introduction}

Biomass burning (BB) is among the major sources of atmospheric pollution with direct short- and long-term climate implications over many regions of the world (Kaskaoutis et al., 2014 and references therein). It is important to quantify BB contribution to aerosol loading over different geographical regions. On the global scale, forest fires and crop-residue burning account for nearly $\sim 90 \%$ of the total wild land fires (Barnaba et al., 2011). In Asia, the emissions from forest fire and crop-residue burning are big contributors $(\sim 45 \%$ and $\sim 34 \%)$ to the total $\mathrm{BB}$ emissions (Streets et al., 2003). India is the second highest crop-residue burning $\left(\sim 84 \mathrm{Tg} \mathrm{yr}^{-1}\right)$ country in Asia (Streets et al., 2003), and crop-residue burning in northern India [northwestern Indo-Gangetic Plain (IGP)] contributes nearly $\sim 20 \%$ to the total global emission budget of carbonaceous aerosol (Rajput et al., 2014a). However, the role of BB in the mitigation policies is often overlooked due to lack of reliable data on their source strength. Several studies over the IGP suggest that BB is the largest source of carbonaceous aerosol (Rengarajan et al., 2007; Ram et al., 2012; Rastogi et al., 2014; Singh and Kaskaoutis, 2014; Choudhary et al., 2017; Satish et al., 2017; Kumar et al., 2018; Sharma et al., 2018); however, studies on the quantification of contribution of BB to ambient organic carbon (OC), and watersoluble OC (WSOC) over the northwestern IGP are scarce. On the global scale, a number of studies had quantified the contribution of BB to ambient OC using

*Authorfor Correspondence: E-mail: atinderastro@gmail.com 
radiocarbon, levoglucosan and biomass burning derived $\mathrm{K}^{+}{ }_{\left(K_{B B}^{+}\right)}$(Gelencser et al., 2007; Gilardoni et al., 2009; Gustafsson et al., 2009). Quantification by radiocarbon is well established technique however; its measurement is very tedious, time consuming, and costly as compared to the measurements of levoglucosan and potassium. Levoglucosan can be used as a unique tracer for BB (Jordan et al., 2006), but it has some limitations because of being unstable in the atmosphere for longer time (Kuo et al., 2008), and relatively difficult to measure in comparison to $\mathrm{K}^{+}$. Although measurement of $\mathrm{K}^{+}$is relatively easy but it is a debatable tracer for identification of $\mathrm{BB}$ because there could be multiple sources of $\mathrm{K}^{+}$in the atmosphere such as BB, mineral dust, sea-salts etc. (Pachon et al., 2013 and references therein). Fine fraction of water-soluble $\mathrm{K}^{+}$can be used as a biomass burning tracer but one should be cautions when applying to coarse particulates (Reche et al., 2012). However, $\mathrm{K}^{+}$has been established as a tracer of $\mathrm{BB}$ over the IGP by several studies (Ram and Sarin, 2011; Rajput et al., 2014b; Singh et al., 2014; Rastogi et al., 2016).

Major objectives of the present study are to assess the contribution of $\mathrm{BB}$ to ambient fine $\mathrm{K}^{+}$ (unlike any of the reported study from this region), and to estimate the contribution of BB to loading of $\mathrm{OC}$ and $\mathrm{WSOC}$ in $\mathrm{PM}_{1}$ (hereafter also referred as fine aerosol).

\section{Experimental Approach}

The present study has been carried out over Patiala $\left(30.33^{\circ} \mathrm{N}, 76.40^{\circ} \mathrm{E} ; 250 \mathrm{~m}\right.$ above mean sea level; Fig. 1 ), which is located in the northwestern part of the IGP during October-2012 to September 2013. Study region experiences two distinct types of large scale agricultural-waste burning episodes i.e., paddy-residue burning during October-November and wheat-residue burning in the month of May (Singh et al., 2016a). Red dots in Fig. 1 (captured with Moderate Resolution Imaging Spectroradiometer (MODIS) onboard polar orbiting NASA's satellite during end of the October month) denote the fire counts, which indicates that high BB activities were present over the study region during that time. For complete description about the sampling site and prevailing emission sources, reference is made to our earlier publications (Rastogi et al., 2015; Singh et al., 2016a; Rastogi et al., 2016).

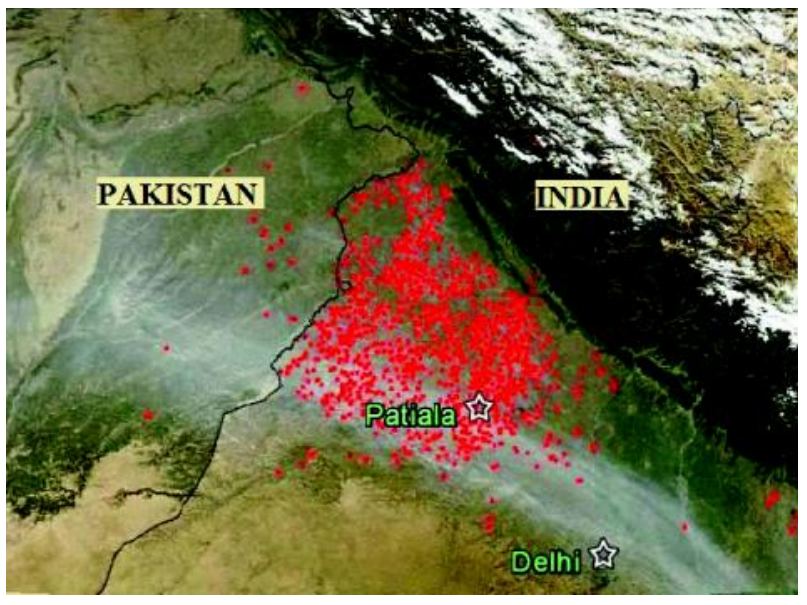

Fig. 1: Map showing sampling location Patiala (Source: Google Erath \&MODIS NASA)

Aerosol samples were collected using 4-stage cascade impactor attached with high volume air sampler (Staplex, USA; Model: 234) at the air flow rate of $1.1 \mathrm{~m}^{3} \mathrm{~min}^{-1}$ with sampling time from 09:0018:00 hrs Indian Standard Time (IST). A total of 52 samples have been collected over an annual cycle and each sample have 5 filters corresponding to the particle collection at five different size ranges i.e., $\mathrm{PM}_{<0.95}\left(\sim \mathrm{PM}_{1}\right), \mathrm{PM}_{0.95-1.5}, \mathrm{PM}_{1.5-3.0}, \mathrm{PM}_{3.0-7.2}$ and $\mathrm{PM}_{>7.2}$. Therefore, the number of analyzed samples were $260(52 \times 5)$. Depending upon the prevailing meteorological conditions over the year, data sets have been classified into five seasons named as autumn (October-November), winter (December-February), spring (March-April), summer (May-June) and wet (July-September), as explained in our earlier publication (Rastogi et al., 2016). The concentrations of $\mathrm{K}^{+}$along with other cations $\left(\mathrm{Na}^{+}, \mathrm{NH}_{4}{ }^{+}, \mathrm{Ca}^{2+}\right.$ and $\left.\mathrm{Mg}^{2+}\right)$ and anions $\left(\mathrm{Cl}^{-}, \mathrm{SO}_{4}{ }^{2-}\right.$ and $\left.\mathrm{NO}_{3}{ }^{-}\right)$were measured in all the five size ranges with dual channel ion chromatograph (Dionex, USA; Model: ICS-5000). In $\mathrm{PM}_{1}$, mass concentrations of elemental carbon (EC) and OC were measured on EC-OC analyzer (Sunset Laboratory, USA; Model: 2000), and that of WSOC on TOC analyzer (Shimadzu, TOC-5000A). Based on replicate analyses of samples, the precision of measurements for water-soluble ionic species, OC and WSOC was found to be $5 \%, 8 \%$ and $4 \%$, respectively. For complete description about the sizesegregated aerosol sampling and their chemical analysis reference is made to our earlier publications (Singh et al., 2016a and 2016b). The average values 
of meteorological parameters, measured by automatic weather station of Indian Meteorological Department (IMD) observatory, Patiala are summarized in Table 1.

\section{Results and Discussion}

During observation period (October 2012 to September 2013), mass concentration of total suspended particulates (TSP; derived by summation of aerosol mass in different size ranges) varied from 88 to 387 $\mu \mathrm{g} \mathrm{m}^{-3}$ with higher concentration (average $\pm \mathrm{sd}$. $\pm 1 \sigma$ ) during autumn (267 \pm 69$)$, summer (227 \pm 77 ), and winter $(179 \pm 55)$ seasons and relatively lower concentration

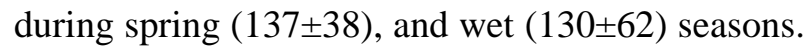
Size-segregated aerosol mass distribution analysis showed that aerosol mass was most abundant ( $55 \%)$ in fine mode $\left(\mathrm{PM}_{1}\right)$, followed by much lower contribution in $\mathrm{PM}_{3.0-7.2}(16 \%)$, and $\mathrm{PM}_{>7.2}(13 \%)$, and least in $\mathrm{PM}_{0.95-1.3}(8 \%)$ and $\mathrm{PM}_{1.5-3.0}(8 \%)$ over the year. High abundance of fine aerosol broadly reflects relatively higher contribution of anthropogenic combustion sources to ambient aerosol loading, as aerosol produced by combustion sources are relatively small in size as compared to natural aerosol produced by physical mechanism (Seinfeld and Pandis, 2006). During autumn, emissions from large scale paddyresidue burning in the open fields are the major source of aerosol loading while during winter, remnant of crop-residue burning and emissions from thermal power plants, bio-fuel (such as Cowdung cake, wood sticks from Babool, Eucalyptus, Jujube and Shisham) and fossil fuel combustion coupled with shallow boundary layer lead to high aerosol loading (Rajput et al., 2011; Singh et al., 2016c). Occurrence of occasional dust storms along with high speed winds and dry atmospheric conditions may cause high concentration of particulates during spring and summer season (Singh et al., 2015). Additionally, emissions from wheat-residue burning during the first half of May (summer) are additional sources of aerosol loading during summer (Singh et al., 2016b). These observations indicate that both anthropogenic as well as natural sources are responsible for high aerosol loading over the site, as reported in our earlier publication (Singh et al., 2015).

\section{Use of Potassium as A Biomass Burning Tracer}

Overall, total mass concentration of $\mathrm{K}^{+}$(sum of concentrations in all the five sizes) varied from 0.06 to $5.3 \mu \mathrm{g} \mathrm{m}^{-3}$ with highest concentration (average \pm sd.; $\pm 1 \sigma$ ) during autumn (3.0 \pm 1.2$)$, followed by a decreasing trend from winter $(1.6 \pm 0.74)$, summer $(0.64 \pm 0.40)$, spring $(0.22 \pm 0.14)$ to wet $(0.19 \pm 0.14)$ season. The $\mathrm{K}^{+}$exhibited high concentration during those seasons when the emissions from agriculturalwaste burning (paddy-residue and wheat-residue during autumn and summer, respectively) and bio-fuel burning (during winter) were dominant.In $\mathrm{PM}_{1}$, a strong linear correlation between $\mathrm{K}^{+}$and $\mathrm{OC}(\mathrm{r}=0.93$; $\mathrm{p}<0.0001$; Fig. not shown) suggests that the emissions from $\mathrm{BB}$ is a dominant source of fine $\mathrm{K}^{+}$. The $\mathrm{K}^{+}$/ $\mathrm{OC}$ ratio in $\mathrm{PM}_{1}$ variedfrom 0.01 to $0.11(0.05 \pm 0.03)$. The $\mathrm{K}^{+} / \mathrm{OC}$ ratio can be used as characteristics of species emitted from different type of biomass burning such as agricultural-waste and bio-fuel. These ratios are comparable to earlier reported ratio of 0.06 over different locations of the IGP (Ram and Sarin, 2011; Rastogi et al., 2014) and tropical forest (0.06, Andreae and Merlet, 2001). However, this ratio is higher than that reported for bio-fuel burning (0.01) and lower than that reported for charcoal burning (0.08) (Andreae and Merlet, 2001). In addition, earlier studies have suggested relatively high OC/EC ratio for carbonaceous aerosol coming from $\mathrm{BB}$ emissions as compared to those from vehicular emissions (fossil fuel emissions) (Sandradewi et al., 2008). In the present study, the temporal variability of fine mode $\mathrm{K}^{+}$and total concentration of $\mathrm{K}^{+}$has shown same trend as exhibited by OC/EC mass ratio, which further confirms the hypothesis that ambient $\mathrm{K}^{+}$over the study region is mainly associated with the $\mathrm{BB}$ emissions.

The study region is surrounded by semi-arid region and thus, dust could also be a possible source of ambient $\mathrm{K}^{+}$along with $\mathrm{BB}$ emissions as there is reasonably significant correlation $(r=0.65 ; \mathrm{p}<0.0001)$ between $\mathrm{Ca}^{2+}$ and $\mathrm{K}^{+}$(Fig. not shown). Pio et al. (2008) proposed a method to distinguish the signal of $\mathrm{K}^{+}$from $\mathrm{BB}$ emissions and dust. They suggested that the enrichment of $\mathrm{K}^{+}$in the $\mathrm{PM}_{2.5}$ is an indicator of dominant contribution of $\mathrm{K}^{+}$from $\mathrm{BB}$ emissions. Thus, to assess the potential source (BB or dust) of ambient $\mathrm{K}^{+}$, fraction of fine mode $\mathrm{K}^{+}\left(\right.$in $\left.\mathrm{PM}_{1}\right)$ in total $\mathrm{K}^{+}$was investigated. The temporal variation in the mass ratio of fine $\mathrm{K}^{+}$to total $\mathrm{K}^{+}$is shown in Fig. $2 \mathrm{~A}$, which depicted that around $80 \%$ (period average) of the total concentration is in fine mode. This observation reveals the dominance of $\mathrm{BB}$ derived $\mathrm{K}^{+}$in comparison to that from natural source (dust) over the study region. 

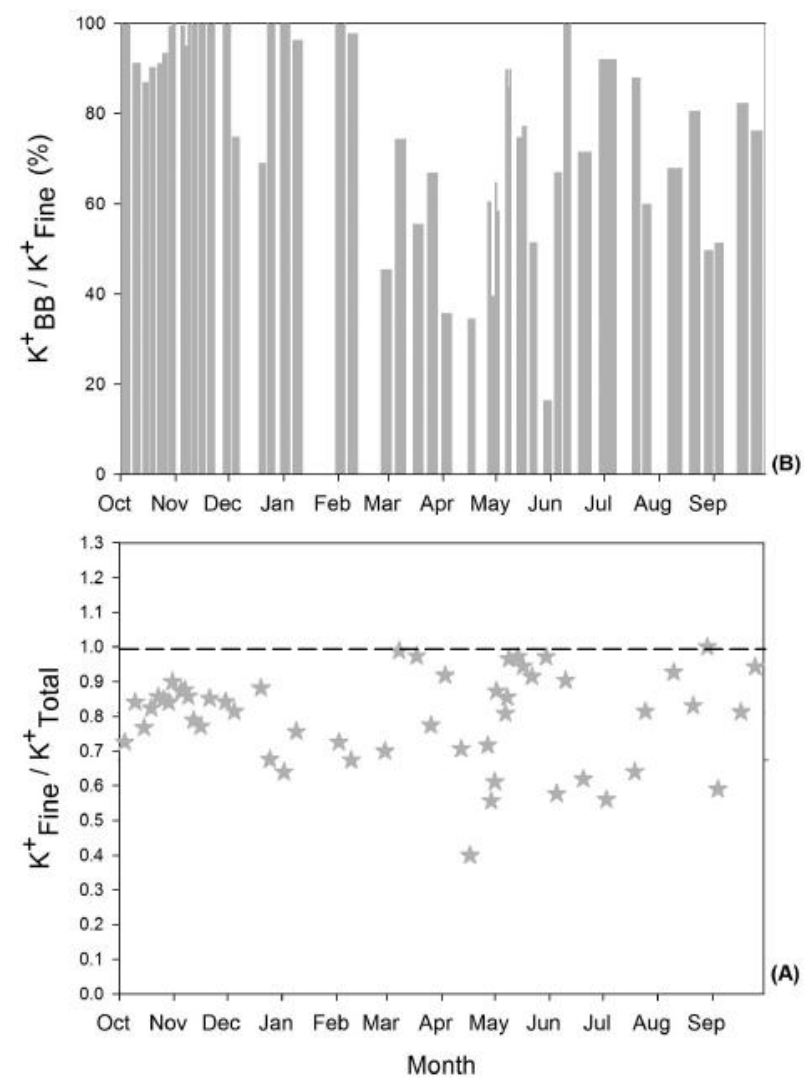

Fig. 2: Temporal variability in the mass ratio of (A) fine potassium in total potassium and (B) biomass burning derived potassium $\left(\mathrm{K}^{+}{ }_{\mathrm{BB}}\right)$ in fine potassium $\left(\mathrm{K}^{+}{ }_{\text {Fine }}\right)$

The concentration of $\mathrm{K}^{+}$corrected for contributions from the dust and sea-salts, has been used as a tracer for BB emissions (Pio et al., 2008). The relationship between $\mathrm{Ca}^{2+}$ and $\mathrm{K}^{+}$in fine mode $\left(\mathrm{PM}_{1}\right)$ has been explored to estimate the concentration of $\mathrm{K}^{+}$not related with mineral dust (Fig. is not shown). Here, the lowest ratio 0.60 is considered as the $\mathrm{K}^{+} /$ $\mathrm{Ca}^{2+}$ ratio in dust. Anything above this ratio reflect the contribution of $\mathrm{K}^{+}$from non-dust sources. Furthermore, this $\mathrm{K}^{+} / \mathrm{Ca}^{2+}$ mass ratio has been used in equation no. (1) to derive the contribution of $K_{B B}^{+}$to fine $\mathrm{K}^{+}$.

$$
\left(K_{B B}^{+}\right)_{\text {Fine }}=K_{n s s}^{+}-0.60\left(C a_{n s s}^{2+}-C a_{B B}^{2+}\right)
$$

Here, $K_{B B}^{+}, K_{n s s}^{+}, C a_{n s s}^{2+}$ and $C a_{B B}^{2+}$ refer to BB derived potassium, non-sea salt (nss) potassium, nsscalcium and BB derived calcium, respectively in $\mathrm{PM}_{1}$. Sea-salt contribution to fine aerosol loading is insignificant over the study region as it is very far from sea shore, and same is reflected in trace amount of measured $\mathrm{Na}^{+}$(annual average $=0.15 \mu \mathrm{g} \mathrm{m}^{-3}$ ). So, nss fraction of potassium and calcium are practically represented by the total measured concentration of potassium and calcium in $\mathrm{PM}_{1}$. Temporal variation in the mass ratio of $K_{B B}^{+}$to the concentration of fine $\mathrm{K}^{+}$ is shown in Fig. 2B. All the samples collected during paddy-residue burning period (October-November) showed $K_{B B}^{+} / \mathrm{K}^{+}$ratio well above 0.9 , and variable fraction has been observed during other months of study. Seasonally, the contribution of to fine $\mathrm{K}^{+}$was high during autumn (96\%), winter (85\%), wet (72\%) and summer (70\%) seasons, and $\sim 46 \%$ during spring season. Significant contribution of to fine $\mathrm{K}^{+}$during autumn and summer is attributed to paddy- and wheatresidue burning in the open fields; whereas during winter, it is mainly due to bio-fuel burning and remnant from the paddy-residue burning. Lowest ratios during spring are ascribed to long-range transported dust from the Thar and Arabian deserts. On annual scale, the contribution ofto fine $\mathrm{K}^{+}$is found to be dominant (77 $\pm 24 \%$ ) over the study region. Earlier study by Pachon et al. (2013) in rural area of the Atlanta, a site mainly influenced by BB emissions, also showed that significant fraction $(82 \%)$ of $\mathrm{K}^{+}$comes from $\mathrm{BB}$. Present study indicates that the dominant source of $\mathrm{K}^{+}$is $\mathrm{BB}$ emissions, and it is reasonable to use fine $\mathrm{K}^{+}$as $\mathrm{BB}$ tracer over the northwestern part of the IGP.

\section{Quantification of Organic Carbon from BB Emissions}

The mass concentrations of OC and WSOC in $\mathrm{PM}_{1}$ ranged from 2.8 to $60(17 \pm 13)$ and 1.9 to $33 \mu \mathrm{g} \mathrm{m}^{-3}$ $(10 \pm 8)$, respectively over an annual cycle. Concentrations of both OC and WSOC are found to be highest during autumn, followed by winter, summer, spring and minimum during wet season (Table 1). Detailed description of temporal trend in the mass concentrations of OC and WSOC are provided in our earlier publication (Singh et al., 2016a). The concentration of in $\mathrm{PM}_{1}$ has been used to quantify the $\mathrm{BB}$ derived $\mathrm{OC}\left(\mathrm{OC}_{\mathrm{BB}}\right)$ in $\mathrm{PM}_{1}$ by literature-based method (Gilardoni et al., 2009). A linear relationship between OC and $K_{B B}^{+}$has been investigated (Fig. 3A), and it was found that the intercept of linear fit is statistically non-zero $\left(7.4 \mu \mathrm{g} \mathrm{m}^{-3}\right)$, indicating the additional source of $\mathrm{OC}$ that does not belong to BB. Therefore, the difference between ambient OC and 
Table 1: Seasonal mean values of temperature (Temp), relative humidity (RH), organic carbon (OC) and watersoluble organic carbon (WSOC) in $\mathbf{P M}_{1}$

\begin{tabular}{lcccc}
\hline Seasons & $\begin{array}{c}\text { Temp }\left({ }^{\circ} \mathrm{C}\right) \\
(\mathrm{Avg} \pm 1 \sigma)\end{array}$ & $\begin{array}{c}\mathrm{RH}(\%) \\
(\mathrm{Avg} \pm 1 \sigma)\end{array}$ & $\begin{array}{c}\text { OC } \\
\left(\mu \mathrm{g} \mathrm{m}^{-3}\right)\end{array}$ & $\begin{array}{c}\text { WSOC } \\
\left(\mu \mathrm{g} \mathrm{m}^{-3}\right)\end{array}$ \\
\hline Autumn & $27 \pm 3$ & $56 \pm 10$ & $31 \pm 15$ & $20 \pm 7.6$ \\
Winter & $17 \pm 4$ & $71 \pm 15$ & $18 \pm 5.5$ & $9.8 \pm 2.6$ \\
Spring & $30 \pm 3$ & $49 \pm 11$ & $10 \pm 1.7$ & $4.7 \pm 1.2$ \\
Summer & $38 \pm 3$ & $54 \pm 13$ & $14 \pm 6.2$ & $8.3 \pm 3.1$ \\
Wet & $34 \pm 2$ & $76 \pm 09$ & $5 \pm 1.8$ & $3.3 \pm 1.2$ \\
\hline
\end{tabular}
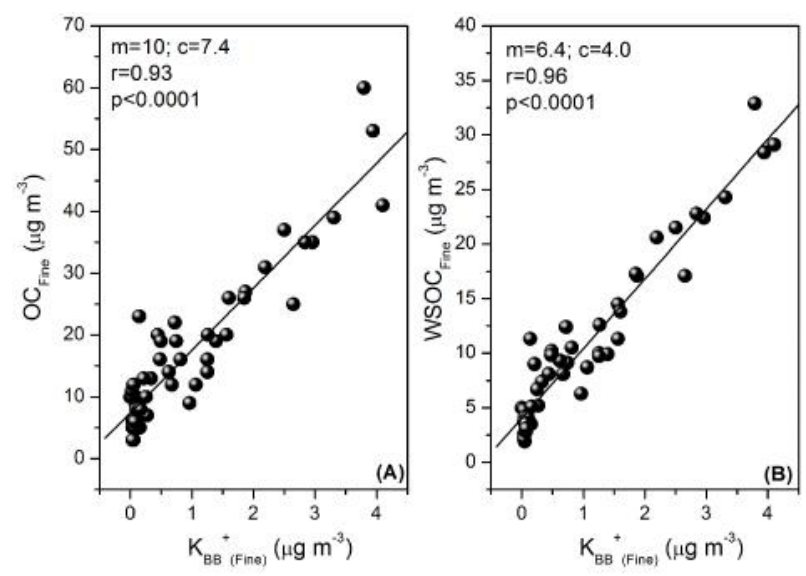

Fig. 3: Relationship between biomass burning derived fine potassium $\left(\mathrm{K}^{+}{ }_{\mathrm{BB}}\right)$ and (A) mass concentration of fine organic carbon $\left(\mathrm{OC}_{\mathrm{Fine}}\right)$, and $(\mathrm{B})$ fine water-soluble organic carbon $\left(\mathrm{WSOC}_{\text {Fine }}\right.$ )

intercept would give the $\mathrm{OC}_{\mathrm{BB}}$. Here, it is relevant to state that accurate estimation of $\mathrm{OC}_{\mathrm{BB}}$ using the current approach is difficult because of several assumptions involved, as also suggested by Pio et al. (2008). Furthermore, intercept (in $\mu \mathrm{g} \mathrm{m}^{-3}$ ) is subtracted from all the data points to estimate $\mathrm{OC}_{\mathrm{BB}}$ which may lead to relatively large error for samples with low concentrations of $\mathrm{OC}$, usually observed during wet season.

Estimated BB contribution to ambient fine OC varied between 0 and $88 \%$ (annual average: $41 \pm 30 \%$ ) (Fig. 4A) with higher contribution during autumn $(69 \%)$, winter $(54 \%)$ and summer $(40 \%)$ seasons, and relatively lower contribution during spring $(26 \%)$ and wet (2\%) seasons, suggesting BB is a significant source of ambient fine OC over the study region especially during autumn, winter and summer seasons. The emissions from large scale paddy-residue burning during autumn and the remnant of crop-residue burning along with emissions from bio-fuel burning during winter are the major factors for high contribution of BB to ambient OC during these seasons. During summer (in May), it is due to wheatresidue burning (Rastogi et al., 2016; Singh et al., 2016a). Relatively lower contribution of BB to ambient $\mathrm{OC}$ during spring and wet seasons is mainly due to absence of any large scale agricultural-waste burning emissions. Over an annual scale, fraction of $K_{B B}^{+}$to fine $\mathrm{K}^{+}$is $77 \%$ but it is not reflected in $\mathrm{OC}$, as contribution of $\mathrm{OC}_{\mathrm{BB}}$ to total $\mathrm{OC}$ is $41 \%$ over an annual cycle. It is due to use of primary tracer in quantification of $\mathrm{OC}_{\mathrm{BB}}$, where $\mathrm{OC}_{\mathrm{BB}}$ mainly represents the fraction of primary organics from $B B$. However, the actual contribution of $\mathrm{BB}$ to ambient OC may be high if secondary OC from BB is also included (Singh et al., 2016b). A study by Jung et al. (2014) over Daejeon, Korea, has reported relatively lower contribution of BB to OC (45\%) as compared to present study (73\%) during the paddy-residue burning period (from mid of October to mid of November).

Recently, Srinivas et al. (2016) had reported $\Delta{ }^{14} \mathrm{C}$ based BB fraction $\left(\mathrm{f}_{\mathrm{BB}-\mathrm{TOC}}\right)$ to total OC in TSP as $0.81 \pm 0.03$ (range: 0.76 to 0.87 ) over Hisar (at a distance of $\sim 180 \mathrm{~km}$ in the southwest of study region) during December month. Hisar also represents a typical semi-urban atmosphere surrounded by agricultural fields like the present study region and situated downwind of sampling site during winter. Present study estimates the contribution of $\mathrm{BB}$ to OC varying from 0.40 to 0.71 (avg: $0.54 \pm 0.18$ ) in $\mathrm{PM}_{1}$ during winter (December to February), which is lower than that reported by Srinivas et al. (2016) in TSP $(0.81 \pm 0.03)$. Quantification in present study is based on the $\mathrm{PM}_{1}$ samplescollected only during daytime, unlike Srinivas et al. (2016). Relatively high contribution of BB to OC abundances had been reported for samples collected during nighttime in comparison to those collected during daytime, because local inhabitants generally burn biomass (bonfire) in the late evening/night during winter to keep themselves and their livestock warm (Rastogi et al., 2014). This could also be one of the possible reasons for lower value of $\mathrm{BB}$ contribution to $\mathrm{OC}$ in present study than that reported by Srinivas et al. (2016). Another possible reason can be the size of particulates under 

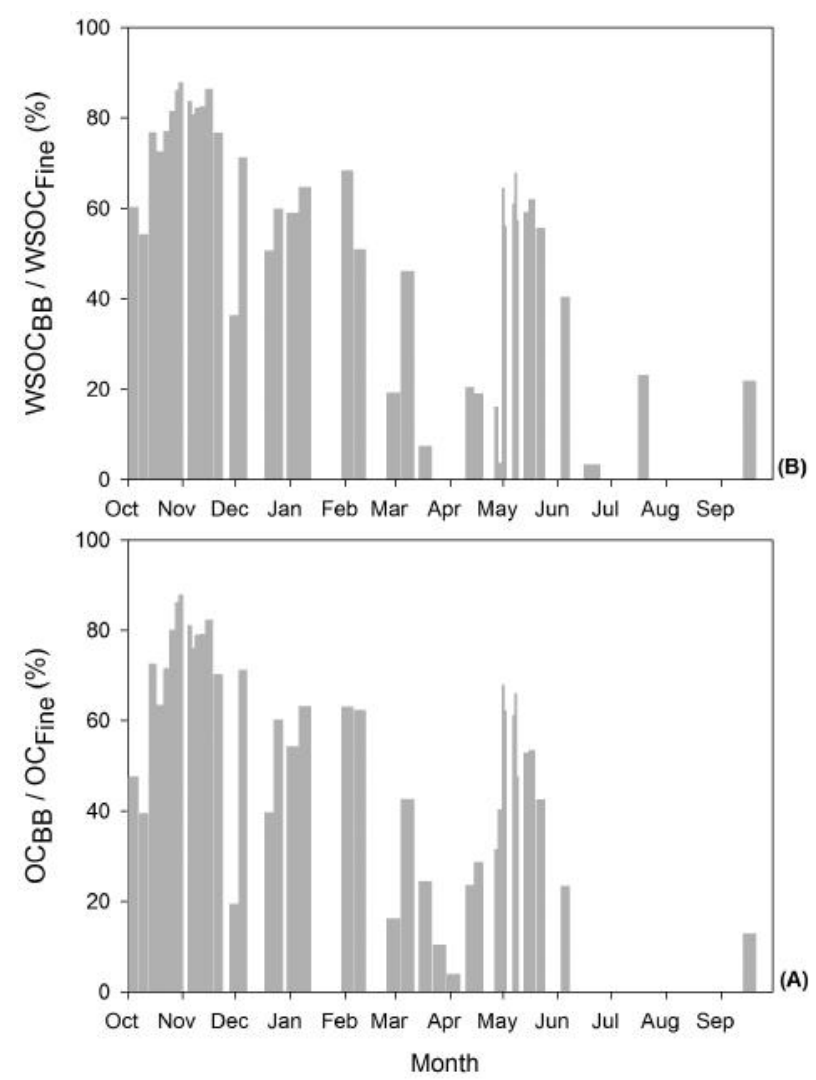

Fig. 4: Fraction of biomass (BB) derived (A) organic carbon (OC) and (B) water-soluble organic carbon (WSOC) in fine aerosol

consideration as aged and other primary organics are generally found in coarse mode ( $>2.5$ micron) (Chalbot et al., 2014). Further, present estimation is based on the primary tracer and represent primary $\mathrm{OC}_{\mathrm{BB}}$, as mentioned earlier. This is well established that estimation using isotopic signature involved relatively less error in comparison to $\mathrm{K}^{+}$based method, however, $\Delta{ }^{14} \mathrm{C}$ measurements are difficult, time consuming, and costly in comparison to the measurement of $\mathrm{K}^{+}$. Hence, present study suggests that one can assess the contribution of $\mathrm{BB}$ to ambient $\mathrm{OC}$ using $\mathrm{K}^{+}$.

The contribution of BB to fine WSOC has also been quantified by employing the same method as used in the case of OC. The intercept in this case is 4 $\mu \mathrm{g} \mathrm{m}^{-3}$ (Fig. 3B), which is subtracted from ambient WSOC to estimate BB derived WSOC. The contribution of $\mathrm{BB}$ to ambient fine WSOC ranged from 0 to $88 \%$ (annual average: $43 \pm 32 \%$ ) over an annual cycle (Fig. 4B). WSOC $_{\mathrm{BB}}$ follows the similar temporal trend as exhibited by $\mathrm{OC}_{\mathrm{BB}}$ with contribution of $75 \%, 55 \%$ and $44 \%$ during autumn, winter and summer seasons respectively, whereas it is found to be $14 \%$ for spring and $5 \%$ for wet season attesting that same sources contribute to $\mathrm{WSOC}_{\mathrm{BB}}$ and $\mathrm{OC}_{\mathrm{BB}}$. In nutshell, present study demonstrates that $\mathrm{BB}$ is significant source of ambient fine $\mathrm{OC}$ and quantify the contribution of $\mathrm{BB}$ to ambient $\mathrm{OC}$, which has important implications in climate models and air quality regulation.

\section{Summary and Conclusions}

In the present study, the impact of BB on ambient $\mathrm{K}^{+}$, OC and WSOC in $\mathrm{PM}_{1}$ have been examined over an annual cycle over Patiala, northwest part of the IGP. BB is found to be the major source of ambient fine $\mathrm{K}^{+}$over the study region with the average contribution of $77 \pm 24 \%$ to total fine $\mathrm{K}^{+}$over an annual cycle. Further, BB derived fine mode $\mathrm{K}^{+}$is used to quantify the contribution of $\mathrm{BB}$ to ambient fine $\mathrm{OC}$. On annual scale, $\mathrm{OC}_{\mathrm{BB}}$ contributes around $41 \pm 30 \%$ to the ambient fine $\mathrm{OC}$ with higher contribution during autumn (69\%), winter (54\%) and summer (40\%) seasons, and relatively lower contribution during spring (26\%) and wet (2\%) seasons. Similarly, the fraction of $\mathrm{WSOC}_{\mathrm{BB}}$ to ambient fine WSOC is found to be significant $(43 \pm 32 \%)$ with seasonal contribution of $75 \%, 55 \%, 14 \%, 44 \%$ and $5 \%$ during autumn, winter, spring, summer and wet, respectively. Agriculturalwaste burning emissions (paddy- and wheat-residue) during autumn and summer, and bio-fuel (such as Babool, Cowdung cake, Eucalyptus, Jujube and Shisham) burning during winter are the major sources of $\mathrm{OC}_{\mathrm{BB}}$. Quantification of $\mathrm{BB}$ contribution to atmospheric OC load is important in climate and air quality models, and may help policy makers in designing the mitigation strategies. This study also provides the baseline data of biomass burning derived OC for the northwestern IGP where biomass burning have a significant impact on the regional and global climate.

\section{Acknowledgements}

Authors are grateful to ISRO, Bangalore for providing the financial support to carry out the present study under ISRO-GBP project. The meteorological data provided by IMD is duly acknowledged. We would like to thank the anonymous reviewers for their valuable comments and suggestions to improve the quality of our manuscript. 


\section{References}

Andreae M O and Merlet P (2001) Emission of trace gases and aerosols from biomass burning in Global Biogeochem $C y$ 15 955-966

Barnaba F, Angelini F, Curci G and Gobbi GP (2011) An important fingerprint of wildfires on the European aerosol load in Atmos Chem Phys 11 10487-10501

Chalbot M C G, Brown J, Chitranshi P, Gamboa da Costa G, Pollock E D and Kavouras I G (2014) Functional characterization of the water-soluble organic carbon of size-fractionated aerosol in the southern Mississippi Valley in Atmos Chem Phys 14 6075-6088

Choudhary V, Rajput P, Rajeev P and Gupta T (2017) Synergetic effect in absorption properties of brown carbon and elemental carbon over IGP during weak south-west monsoon in Aerosol Sci Eng 1 138-149

Gelencser A, May B, Simpson D, Sanchez-Ochoa A, KasperGiebl A, Puxbaum H, Caseiro A, Pio C and Legrand M (2007) Source apportionment of $\mathrm{PM}_{2.5}$ organic aerosol over Europe: Primary/secondary, natural/anthropogenic, and fossil/biogenic origin in J Geophys Res 112. doi:10.1029/ 2006JD008094

Gilardoni S, Liu S, Takahama S, Russell L M, Allan J D, Steinbrecher R, Jimenez J L, De Carlo P F, Dunlea E J and Baumgardner D (2009) Characterization of organic ambient aerosol during MIRAGE 2006 on three platforms in Atmos Chem Phys $95417-5432$

Gustafsson Ö, Kruså M, Zencak Z, Sheesley RJ, Granat L, Engström E, Praveen P, Rao P, Leck C and Rodhe H (2009) Brown clouds overSouth Asia: Biomass or fossil fuel combustion? in Science 323 495-498

Jordan T B, Seen A J and Jacobsen G E (2006) Levoglucosan as an atmospheric tracer for wood smoke in Atmos Environ 40 5316-5321

Jung J, Lee S, Kim H, Kim D, Lee H and Oh S (2014)Quantitative determination of the biomass-burning contribution to atmospheric carbonaceous aerosols in Daejeon, Korea, during the rice-harvest period in Atmos Environ 89642 650

Kaskaoutis D G, Kumar S, Sharma D, Singh R P, Kharol S K, Sharma M, Singh AK, Singh S, Singh A and Singh D (2014) Effects of crop residue burning on aerosol properties, plume characteristics, and long range transport over northern India in J Geophys Res 119 5424-5444

Kumar S, Nath S, Bhatti M S and Yadav S (2018) Chemical Characteristics of Fine and Coarse Particles during Wintertime over Two Urban Cities in North India in Aerosol
Air Qual Res 18 1573-1590

Kuo Li-J, Herbert B E and Louchouarn P (2008) Can levoglucosan be used to characterize and quantify char/charcoal black carbon in environmental media? in Org Geochem 39 14661478

Pachon J E, Weber R J, Zhang X, Mulholland J A and Russell A G (2013) Revising the use of potassium (K) in the source apportionment of $\mathrm{PM}_{2.5}$ in Atmos Pollut Res 4 14-21

Pio C A, Legrand M, Alves C A, Oliveira T, Afonso J, Caseiro A, Puxbaum H, Sanchez-Ochoa A and Gelencsér A (2008) Chemical composition of atmospheric aerosols during the 2003 summer intense forest fire period in Atmos Environ $427530-7543$

Rajput P, Sarin M M, Rengarajan R and Singh D (2011) Atmospheric polycyclic aromatic hydrocarbons (PAHs) from post-harvest biomass burning emissions in the IndoGangetic Plain: Isomer ratios and temporal trends in Atmos. Environ 45 6732-6740

Rajput P, Sarin M M, Sharma D and Singh D (2014a) Characteristics and emission budget of carbonaceous species from postharvest agricultural-waste burning in source region of the Indo-Gangetic Plain in Tellus B 66 . doi: 10.1039/c4em00307a

Rajput P, Sarin M M, Sharma D and Singh D (2014b) Organic aerosols and inorganic species from postharvest agricultural-waste burning emissions over northern India: impact on mass absorption efficiency of elemental carbon in Enviorn Sci Processes Impacts 16 2371-2379. doi: 10.1039/c4em00307a

Rengarajan R, Sarin M M and Sudheer A K (2007) Carbonaceous and inorganic species in atmospheric aerosols during wintertime over urban and high-altitude sites in North India in J Geophys Res 112 1-16. doi:10.1029/ 2006JD008150

Ram K and Sarin M M (2011) Day-night variability of EC, OC, WSOC and inorganic ions in urban environment of IndoGangetic Plain: Implications to secondary aerosol formation in Atmos Environ 45 460-468

Ram K, Sarin M M and Tripathi S N (2012) Temporal Trends in Atmospheric $\mathrm{PM}_{2.5}, \mathrm{PM}_{10}$, Elemental Carbon, Organic Carbon, Water-Soluble Organic Carbon, and Optical Properties: Impact of Biomass Burning Emissions in the Indo-Gangetic Plain in Environ Sci Tech 46 686-695

Rastogi N, Singh A, Singh D and Sarin M M (2014) Chemical characterization of $\mathrm{PM}_{2.5}$ at a source region of biomass burning emissions: Evidence for secondary aerosol formation in Environ Pollut 184 563-569 
Rastogi N, Patel A, Singh A and Singh D (2015) Diurnal variability in secondary organic aerosol formation over Indo-Gangetic Plain during winter using online measurement of watersoluble organic carbon in Aerosol Air Qual Res 152225 2231

Rastogi N, Singh A, Sarin M Mand Singh D (2016) Temporal variability of primary and secondary aerosols over northern India: Impact of biomass burning emissions in Atmos Environ 125 396-403. doi: 10.1016/j.atmosenv.2015. 06.010

Reche C, Viana M, Amato F, Alastuey A, Moreno T, Hillamo R, Teinilä K, Saarnio K, Seco R, Peñuelas J, Mohr C, Prévôt A S H and Querol X (2012) Biomass burning contributions to urban aerosols in a coastal Mediterranean city in $\mathrm{Sci}$ total Environ 427/428 175-190

Sandradewi J, Prévôt A S H, Szidat S, Perron N, Alfarra R M, Lanz V A, Weingartner E and Baltensperger U (2008) Using aerosol light absorption measurements for the quantitative determination of wood burning and Traffic emission contributions to particulate matter in Environ Sci Technol 42 3316-3323

Satish R, Shamjad P, Thamban N, Tripathi S and Rastogi N (2017) Temporal characteristics of brown carbon over the central Indo-Gangetic Plain in Environ Sci Technol 51 67656772

Seinfeld J Hand Pandis S N (2006) Atmospheric chemistry and physics: From air pollution to climate change. John Wiley \& Sons, New York, USA

Sharma S K, Mandal T K, Sharma A, Jain S and Saraswati (2018) Carbonaceous Species of $\mathrm{PM}_{2.5}$ in Megacity Delhi, India During 2012-2016 in Bull Environ Contam Toxicol 100 695-701

Singh A, Rajput P, Sharma D, Sarin M M and Singh D (2014)
Black carbon and elemental carbon from post-harvest agricultural-waste burning emissions in the Indo-Gangetic Plain in Adv Meteorol 20141-10. ID 179301. doi: 10.1155/ 2014/179301

Singh A, Rastogi N, Sharma D and Singh D (2015) Inter and intraannual variability in aerosol characteristics over northwestern Indo-Gangetic Plain in Aerosol Air Qual Res $15376-386$

Singh A, Rastogi N, Patel A, Satish R V and Singh D (2016a) Sizesegregated characteristics of carbonaceous aerosols over the Northwestern Indo-Gangetic Plain: Year round temporal behavior in Aerosol Air Qual Res 16 1615-1624

Singh A, Rastogi N, Patel A and Singh D (2016b) Seasonality in size-segregated ionic composition of ambient particulate pollutants over the Indo-Gangetic Plain: Source apportionment using PMF in Environ Pollut 219 906-915

Singh A, Srivastava R, Rastogi N and Singh D (2016c) Absorbing and scattering aerosols over the source region of biomass burning emissions: Implications in the assessment of optical and radiative properties in Atmos Environ 127 6168

Singh R P and Kaskaoutis D G (2014) Crop residue burning: A threat to south Asian air quality in EoS 95 333-334

Srinivas B, Andersson A, Sarin M M, Sheesley R J, Kirillova E, Rengarajan R, Sudheer A K, Ram K and Gustafsson Ö (2016) Dual carbon isotope characterization of total organic carbon in wintertime carbonaceous aerosols from northern Indiain J Geophys Res 121 4797-4809. doi:10.1002/ 2016JD024880

Streets D G, Yarber K F, Woo J -H and Carmichael G R (2003) Biomass burning in Asia: Annual and seasonal estimates and atmospheric emissions in Global Biogeochem Cy 17. doi: 10.1029/2003GB002040. 